\title{
Improving node number simulation in soybean
}

\author{
Nereu Augusto Streck ${ }^{(1)}$, Gizelli Moiano de Paula ${ }^{(1)}$, Felipe Brendler Oliveira ${ }^{(1)}$, \\ Ana Paula Schwantes ${ }^{(1)}$ and Nilson Lemos de Menezes ${ }^{(1)}$
}

(1)Universidade Federal de Santa Maria, Avenida Roraima, no 1.000, Bairro Camobi, CEP 97105-900 Santa Maria, RS, Brazil. E-mail: nstreck2@yahoo.com.br, gizellidepaula@gmail.com, felipebrendler@msn.com, aninha tapera@hotmail.com, nlmenezes@smail.ufsm.br

\begin{abstract}
The objective of this study was to improve the simulation of node number in soybean cultivars with determinate stem habits. A nonlinear model considering two approaches to input daily air temperature data (daily mean temperature and daily minimum/maximum air temperatures) was used. The node number on the main stem data of ten soybean cultivars was collected in a three-year field experiment (from 2004/2005 to 2006/2007) at Santa Maria, RS, Brazil. Node number was simulated using the Soydev model, which has a nonlinear temperature response function $[\mathrm{f}(\mathrm{T})]$. The $\mathrm{f}(\mathrm{T})$ was calculated using two methods: using daily mean air temperature calculated as the arithmetic average among daily minimum and maximum air temperatures (Soydev $v_{\text {tmean }}$ ); and calculating an $\mathrm{f}(\mathrm{T})$ using minimum air temperature and other using maximum air temperature and then averaging the two $\mathrm{f}(\mathrm{T}) \mathrm{s}$ ( $\operatorname{Soydev}_{\mathrm{tmm}}$ ). Root mean square error (RMSE) and deviations (simulated minus observed) were used as statistics to evaluate the performance of the two versions of Soydev. Simulations of node number in soybean were better with the Soydev $v_{\text {tmm }}$ version, with a 0.5 to 1.4 node RMSE. Node number can be simulated for several soybean cultivars using only one set of model coefficients, with a 0.8 to 2.4 node RMSE.
\end{abstract}

Index terms: Glycine max, node appearance rate, vegetative development, V-stages.

\section{Melhoria na simulação do número de nós em soja}

Resumo - O objetivo deste trabalho foi melhorar a simulação do número de nós em cultivares de soja de hábito de crescimento determinado. Foi utilizado um modelo não linear que considera duas abordagens para entrada dos dados de temperatura diária do ar (temperatura média diária e temperaturas mínima/máxima diárias). Foram usados dados de número de nós na haste principal de dez cultivares de soja coletados em um experimento de campo durante três anos (de 2004/2005 a 2006/2007) em Santa Maria, RS. O número de nós foi simulado com o modelo Soydev, que tem uma função não linear de resposta à temperatura $[\mathrm{f}(\mathrm{T})]$. A f(T) foi calculada por dois métodos: pela temperatura média diária do ar, determinada pela média aritmética entre as temperaturas mínima e máxima diárias ( $\operatorname{Soydev}_{\text {tmédia }}$ ), e pela média entre os valores das $\mathrm{f}(\mathrm{T}) \mathrm{s}$ da temperatura mínima do ar e da temperatura máxima do ar $\left(\operatorname{Soydev}_{\mathrm{tmm}}\right)$. A raiz do quadrado médio do erro (RQME) e os desvios (simulado menos observado) foram as estatísticas usadas para avaliar o desempenho das duas versões do Soydev. A simulação do número de nós em soja foi melhor com a versão $\operatorname{Soydev}_{\text {tmm }}$, com um RQME de 0,5 a 1,4 nós. O número de nós pode ser simulado em várias cultivares de soja usando-se apenas um conjunto de coeficientes, com uma RQME entre 0,8 e 2,4 nós.

Termos para indexação: Glycine max, taxa de aparecimento de nós, desenvolvimento vegetativo, estádios-V.

\section{Introduction}

The calculation of node appearance rate (NAR) is an important part of simulation models for soybean [Glycine $\max ($ L.) Merrill] growth, development and yield (Jones \& Laing, 1978; Sinclair, 1986; Sinclair et al., 2005). Integrating NAR over time results in the accumulated number of nodes on a stem (NN), which is an excellent measurement for plant development (Streck et al., 2006). The $\mathrm{NN}$ is also related to the timing of the developmental stages. In the most widely used phenology staging system for soybean by
Fehr \& Caviness (1977), vegetative development (VD) is described by assigning a number based on the status of the leaf on a node above it. The VD is coded as V-stages, so that $\mathrm{VC}=$ cotyledonary stage (the edges of the unifoliate leaf pair are not touching), $\mathrm{V} 1$ = unifoliate leaf pair is expanded and the edges of the first trifoliolate leaf are not touching, and so forth until $\mathrm{Vn}=$ the last main stem node. Other developmental stages in soybean, such as R1 (beginning of flowering), R3 (beginning pod), and R5 (beginning seed) are also related to $\mathrm{NN}$, as the vegetative phase (from emergence

Pesq. agropec. bras., Brasília, v.44, n.7, p.661-668, jul. 2009 
to the end of node appearance) overlaps the reproductive phase (from R1 to physiological maturity) (Johnson, 1997). The NN is also related to the expansion of leaf area index (Sinclair, 1986).

There are several models to simulate soybean development (Major et al., 1975; Jones \& Laing, 1978; Piper et al., 1996; Jones et al., 2000; Wolf, 2002). Setiyono et al. (2007) developed a soybean phenology model, named Soydev model, in which developmental events are simulated considering five main phases: emergence, main stem node appearance, flowering, pod and seed set, and maturity. Soydev is a model that assembles the current knowledge about the response of soybean development to environmental factors. For the main stem node appearance phase in Soydev, temperature drives development and the temperature response function $[\mathrm{f}(\mathrm{T})]$ is calculated using a nonlinear beta function. Simulation of V-stages of 20 soybean cultivars in the Central Great Plains of the USA using Soydev improved when compared to the simulations using the Cropgro model, which uses a linear spline function for [f(T)] (Jones et al., 2000).

Soydev was calibrated and evaluated for two types of stem termination soybean groups (indeterminate and semi-determinate) grown under non-limiting water and nutrient conditions in a high-latitude temperate region (Setiyono et al., 2007). Commercial soybean cultivars currently grown in Brazil are adapted for low-latitude tropical and subtropical environments, have determinate stem termination habits (Sinclair et al., 2005) and are mainly grown under rainfed conditions. Thus, further calibration and evaluation of the Soydev model under Brazilian conditions is required, which constituted one rationale for this study.

Another rationale for this study is related to the calculation of $f(T)$. There are two approaches to input daily temperature data for $\mathrm{f}(\mathrm{T})$ : calculating the daily mean temperature (Tmean, calculated as the average of minimum and maximum daily temperatures or as the average of 24-hour temperatures) and then using the Tmean to calculate one daily $\mathrm{f}(\mathrm{T})$ (Streck et al., 2003a, b; Streck et al., 2006; Martins \& Streck, 2007; Streck et al., 2007, 2008b); and calculating $\mathrm{f}(\mathrm{T})$ for each daily temperature (minimum and maximum temperature or 24-hour values) and then averaging the $\mathrm{f}(\mathrm{T})$ values, thus obtaining a daily mean f(T) (Xue et al., 2004; Streck et al., 2008c). The latter approach works better when air temperatures are near the cardinal temperatures
(Streck et al., 2008c). Soydev uses the former approach for $\mathrm{f}(\mathrm{T})$ (Setiyono et al., 2007), but when soybean is grown in low latitude and under rainfed conditions, like in Brazil, it is expected that air temperatures during the growing season fall into the supra-optimum temperature range more often than in the high-latitude and irrigated conditions with which Soydev was calibrated and evaluated. Therefore, calculating $\mathrm{f}(\mathrm{T})$ based on daily minimum and maximum air temperature might improve the simulation of soybean NN using Soydev under Brazilian conditions in comparison to the original version of the model.

The objective of this study was to improve the node number simulation in determinate stem termination habit soybean cultivars.

\section{Materials and Methods}

The data used in this study were from a three-year field experiment using ten soybean cultivars with determinate stem termination habits (Table 1), conducted at Departamento de Fitotecnia, Universidade Federal de Santa Maria, Santa Maria, RS, Brazil (29\%43'S, $53^{\circ} 43^{\prime} \mathrm{W}, 95 \mathrm{~m}$ altitude), during the 2004/2005, $2005 / 2006$ and 2006/2007 growing seasons. This region has a wet subtropical climate with warm summers (Cfa formula according to Köppen System). The soil type at the experimental site was an Argissolo Bruno-Acinzentado alítico úmbrico (Rhodic Paleudalf) (Streck et al., 2008a). Tillage consisted of plowing and disking for seedbed preparation. Weeds were controlled by manual hoeing, and insects and diseases were controlled by spraying chemical insecticides and fungicides in order to avoid stress by biotic factors. Six cultivars were used in the 2004/2005 growing season, five cultivars in the 2005/2006 growing season and two cultivars in the 2006/2007 growing season totaling ten cultivars (CD 205 was used in all three years and CD 209 was used in the last two years) with distinct developmental cycles, varying from early to mid-late maturation (Table 1).

The experimental design was a completely randomized block with two replicates (plots with three $3 \mathrm{~m}$-long rows and $0.5 \mathrm{~m}$ spacing between rows) in 2004/2005 and three replicates (plots with four $4 \mathrm{~m}$-long rows and $0.5 \mathrm{~m}$ spacing between rows) in 2005/2006. Plant density in 2004/2005 and in 2005/2006 was of 40 plants $\mathrm{m}^{-2}$. In the $2006 / 2007$ growing season, two 
cultivars (CD 205 and CD 209) and three plant densities $\left(24,32\right.$ and 40 plants $\left.\mathrm{m}^{-2}\right)$ were arranged in a factorial scheme with three replicates (plots with four $4 \mathrm{~m}$-long rows with $0.5 \mathrm{~m}$ spacing between rows). Fertilization followed local recommendations.

The sowing dates were December $3^{\text {rd }}, 2004$; November $23^{\text {rd }}, 2005$ and December $2^{\text {nd }}, 2006$ in the three growing seasons, respectively, which are within the recommended sowing period for this region (Reunião de Pesquisa de Soja da Região Sul, 2007). Emergence was determined in each plot by counting the number of visible plants above soil surface on a daily basis. The date of emergence was the average among the dates when $50 \%$ of plants with cotyledons appeared above soil surface in each plot. One week after emergence, five plants in the center row in the 2004/2005 growing season, and six plants in the two center rows in the 2005/2006 and 2006/2007 growing seasons were randomly selected and tagged with colored wires. In these selected plants, the number of visible nodes $(\mathrm{NN})$ on the main stem was counted three times a week (every other day, from Monday to Friday). A node was assumed visible when the edges of at least one of the foliolates of the leaf associated to the node were not touching (Johnson, 1997). The NN was considered the average of the tagged plants. The final node number (FNN) on the main stem of the tagged plants was counted at the end of the experiment.

Daily minimum (TN) and maximum (TX) air temperature and precipitation data during the node appearance phase were measured using a conventional weather station (Instituto Nacional de Meteorologia) located about $300 \mathrm{~m}$ distant from the plots.
The Soydev model (Setiyono et al., 2007) used in this study is a mechanistic model that has two important features: the genotype component and the environment component are combined in a multiplicative fashion, and environmental factors that drive development (i.e. temperature) are represented by nonlinear response functions that vary from zero to one. The node number in Soydev is calculated by (Setiyono et al., 2007):

NAR $=\mathrm{NAR}_{\max } f(T)$, where NAR is the daily node appearance rate (nodes per day), $\mathrm{NAR}_{\max }$ is the maximum daily node appearance rate (nodes per day) under optimum temperature, and $\mathrm{f}(\mathrm{T})$ is a dimensionless temperature response function $(0-1)$ for NAR. Temperature response funtion is a beta function:

$\mathrm{f}(\mathrm{T})=\left[2\left(\mathrm{~T}-\mathrm{T}_{\min }\right)^{\alpha}\left(\mathrm{T}_{\mathrm{opt}}-\mathrm{T}_{\min }\right)^{\alpha}-\left(\mathrm{T}-\mathrm{T}_{\min }\right)^{2 \alpha}\right] /\left(\mathrm{T}_{\mathrm{opt}}-\mathrm{T}_{\min }\right)^{2 \alpha}$ $\alpha=\ln 2 / \ln \left[\left(\mathrm{T}_{\max }-\mathrm{T}_{\min }\right) /\left(\mathrm{T}_{\text {opt }}-\mathrm{T}_{\min }\right)\right]$,

where $T_{\text {min }}, T_{\text {opt }}$, and $T_{\max }$ are the cardinal temperatures (minimum, optimum, and maximum) for NAR, and $\mathrm{T}$ is the daily air temperature. The cardinal temperatures for NAR are $7.6,31$ and $40^{\circ} \mathrm{C}$ for $\mathrm{T}_{\min }, \mathrm{T}_{\mathrm{opt}}$, and $\mathrm{T}_{\max }$, respectively (Setiyono et al., 2007). The main stem NN is calculated by accumulating daily NAR values (i.e. at a one-day-time step) starting at the emergence date, i.e., $\mathrm{NN}=\sum \mathrm{NAR}$.

Temperature response function in the Soydev model was calculated using two different approaches: using daily mean air temperature calculated as the arithmetic average $\left(\mathrm{T}_{\text {mean }}\right)$ of daily TN and TX (Soydev $\left.v_{\text {tmean }}\right)$; and calculating a $f(T)$ using $T N$ and a $f(T)$ using TX and then averaging the two $f(T) s\left(\operatorname{Soydev}_{\text {tmm }}\right)$. The $\mathrm{NAR}_{\max }$ coefficient is genotype-dependent and was estimated for cultivars CD 205 and CD 209 using the NN data

Table 1. Soybean cultivars used in the study during the three growing seasons ${ }^{(1)}$.

\begin{tabular}{|c|c|c|c|c|c|}
\hline Cultivar & $\begin{array}{l}\text { Maturity } \\
\text { group }\end{array}$ & $\begin{array}{l}\text { Emergence date } \\
\text { (day/month/year) }\end{array}$ & $\begin{array}{c}\text { Recommended } \\
\text { region }\end{array}$ & Company & $\begin{array}{l}\text { Year of } \\
\text { release }\end{array}$ \\
\hline \multicolumn{6}{|c|}{$2004 / 2005$ growing season } \\
\hline CD 203 & Early & $11 / 10 / 2004$ & $\mathrm{RS}, \mathrm{SC}$ & Ocepar/Coodetec & 1997 \\
\hline FT 9 & Mid-early & $10 / 12 / 2004$ & PR & FT Sementes & 1984 \\
\hline CD 201 & Mid-early & $11 / 10 / 2004$ & $\mathrm{RS}, \mathrm{SC}$ & Coodetec & 1997 \\
\hline BRS 66 & Medium & $11 / 10 / 2004$ & RS & Embrapa & 1996 \\
\hline Fundacep 39 & Medium & $11 / 12 / 2004$ & RS & Fundacep & 2001 \\
\hline CD 205 & Mid-late & $10 / 12 / 2004$ & $\mathrm{RS}, \mathrm{SC}$ & Ocepar/Coodetec & 1998 \\
\hline \multicolumn{6}{|c|}{$2005 / 2006$ growing season } \\
\hline CD 213 RR & Early & $20 / 11 / 2005$ & $-(2)$ & Coodetec & - \\
\hline CD 214 RR & Early & $29 / 11 / 2005$ & - & Coodetec & - \\
\hline CD 209 & Medium & $2 / 12 / 2005$ & $\mathrm{RS}, \mathrm{SC}$ & Ocepar/Coodetec & - \\
\hline CD 205 & Mid-late & $1 / 12 / 2005$ & $\mathrm{RS}, \mathrm{SC}$ & Ocepar/Coodetec & 1997 \\
\hline CD $219 \mathrm{RR}$ & Mid-late & $2 / 12 / 2005$ & RS & Coodetec & - \\
\hline \multicolumn{6}{|c|}{$2006 / 2007$ growing season } \\
\hline CD 209 & Medium & $2 / 12 / 2006$ & $\mathrm{RS}, \mathrm{SC}$ & Ocepar/Coodetec & - \\
\hline CD 205 & Mid-late & $2 / 12 / 2006$ & $\mathrm{RS}, \mathrm{SC}$ & Ocepar/Coodetec & 1997 \\
\hline
\end{tabular}

(1)Sources: Associação dos Produtores e Comerciantes de Sementes do Rio Grande do Sul (2006), Cooperativa Central de Pesquisa Agrícola (2006) and Fundação Centro de Experimentação e Pesquisa (2006). ${ }^{(2)}$ Data not available. 
collected from the 40 plants $\mathrm{m}^{-2}$ treatment in the 2006/2007 growing season. The $\mathrm{NAR}_{\max }$ coefficient was estimated by changing (increasing and decreasing) an initial value ( 0.4 nodes per day) by a $1 \%$ step until obtaining the best fit between observed and simulated values - least square method (Xue et al., 2004) with an algorithm in Excel software.

The performance of the two versions of the Soydev node appearance model was evaluated using the NN data of cultivar CD 205 grown in the 2004/2005 and 2005/2006 growing seasons and NN data of cultivar CD 209 grown in the 2005/2006 growing season, which are independent data sets. The NN data for cultivars CD 205 and CD 209 collected in the 32 plants $\mathrm{m}^{-2}$ and 24 plants $\mathrm{m}^{-2}$ treatments during the 2006/2007 growing season were also used to evaluate the two versions of the model in order to test the models when a field management is changed (change in plant density). The recommended plant density for soybean in southern Brazil has changed from 40 plants $\mathrm{m}^{-2}$ in the early 2000's (Reunião de Pesquisa de Soja da Região Sul, 2000) to $30-32$ plants $\mathrm{m}^{-2}$ in the $2006 / 2007$ growing season (Reunião de Pesquisa de Soja da Região Sul, 2006, 2007). The density of 24 plants $\mathrm{m}^{-2}$ represents field situations that can happen when the number of emerged soybean plants is low due to stress factors such as low soil moisture, low or high temperature, seed damage by insects, among others.

A second evaluation of the Soydev model was performed for simulating the $\mathrm{NN}$ of the other eight soybean cultivars (Table 1). Because these cultivars were grown in a single sowing date, there is no calibration data set plus independent data set for these cultivars. In this second evaluation, the version of the Soydev model with best performance for cultivars CD 205 and CD 209 was run for each of the other eight cultivars using the $\mathrm{NAR}_{\max }$ estimated for the cultivar CD 205 and the $\mathrm{NAR}_{\text {max }}$ estimated for the cultivar CD 209. This alternative evaluation was used to test the ability of Soydev to simulate NN without the need for cultivar-specific calibration and to identify cultivars that have similar node appearance rates, as data for calibrating individual cultivars are often not available and commercial soybean cultivars change frequently.

The statistic root mean square error (RMSE) was calculated with the independent data and used as a measure of the models' performance. The RMSE was calculated as (Janssen \& Heuberger, 1995): RMSE $=\left[\Sigma\left(\mathrm{S}_{\mathrm{i}}-\mathrm{O}_{\mathrm{i}}\right)^{2} / \mathrm{n}\right]^{0.5}$, where $S_{i}$ are simulated $N N$ data, $O_{i}$ are observed $N N$ data, $n$ is the number of observations, and $\mathrm{i}$ varies from 1 to $\mathrm{n}$.
The RMSE expresses the spread in $\mathrm{S}_{\mathrm{i}}-\mathrm{O}_{\mathrm{i}}$ and has the same units as the predicted and the observed data (in this study the unit is nodes). The lower the RMSE, the better the model simulation. The method based on the deviations (simulated minus observed) proposed by Mitchell (1997) was also used for assessing models performance. The approach of regressing simulated versus observed $\mathrm{NN}$ was avoided in this study, since it has been suggested that this method is not appropriate for assessing model performance (Harisson, 1990; Mitchell, 1997). Pearson correlation between simulated and observed $\mathrm{NN}$ values, and normality and homogeneity of variance of observed and simulated NN values were also performed for model evaluation (Martin et al., 2007), using the Kolmogorow-Smirnov and Bartlett tests, respectively.

\section{Results and Discussion}

Meteorological conditions (temperature and precipitation) during the node appearance phase were distinct in the three growing seasons. The 2006/2007 growing season, which was used to estimate $\mathrm{NAR}_{\max }$, was the mildest and the wettest. During 13 weeks of node appearance in the 2006/2007 growing season, the average weekly minimum temperature varied from 18.3 to $22.6^{\circ} \mathrm{C}$ and the average weekly maximum temperature varied from 27.6 to $33.8^{\circ} \mathrm{C}$, and the total precipitation was $448.2 \mathrm{~mm}$. The 2004/2005 growing season was the warmest, with the highest average weekly maximum temperature $\left(36^{\circ} \mathrm{C}\right)$, and the driest, with $142.4 \mathrm{~mm}$ of precipitation during 13 weeks of node appearance. The 2005/2006 growing season was intermediate in terms of precipitation (302.8 mm during 11 weeks of node appearance) and had the lowest average weekly minimum temperature $\left(15.2^{\circ} \mathrm{C}\right)$. Maximum air temperature exceeded the optimum temperature for NAR $\left(31^{\circ} \mathrm{C}\right)$ in most weeks during the node appearance phase, mainly in the 2004/2005 growing season, while minimum air temperature was always above minimum temperature for NAR $\left(7.6^{\circ} \mathrm{C}\right)$ in all three growing seasons. These distinct meteorological conditions in the three growing seasons represent expected interannual climate variability for this location and are appropriate for calibrating and evaluating the two versions of the Soydev node appearance model.

The estimated $\mathrm{NAR}_{\max }$ for cultivar CD 205 was of 0.4088 nodes per day and 0.3736 nodes per day and for cultivar CD 209 was of 0.4237 nodes per day and 0.4027 nodes per day with Soydev $_{\text {tmean }}$ and Soydev $_{\text {tmm }}$, respectively. 
Simulated versus observed values of main stem NN for the independent data of cultivars CD 205 and CD 209 are presented in Figure 1. Pooling the data of the two cultivars during the 2004/2005 and 2005/2006 growing seasons, the RMSE was of 2.1 nodes with the Soydev tmean $_{\text {version of the model }}$ (Figure $1 \mathrm{~A}$ ) and of 1.3 nodes with the $\operatorname{Soydev}_{\mathrm{tmm}}$ version (Figure $1 \mathrm{~B}$ ). The RMSE was also reduced from 2.1 nodes (Figure $1 \mathrm{C}$ ) to 1.0 node (Figure $1 \mathrm{D}$ ) when the NN of the two cultivars grown in 2006/2007 at 24 and 32 plants $\mathrm{m}^{-2}$ was simulated using Soydev ${ }_{\text {tmean }}$ and Soydev $_{\text {tmm }}$, respectively. A consistent overprediction of the NN was observed with the Soydev tmean version of the model, as the residuals (simulated minus observed) were positive and curved up as the crop aged (insets of Figures $1 \mathrm{~A}$ and $1 \mathrm{C}$ ), with residuals greater than two nodes for NN higher than ten nodes. Simulations of NN using the Soydev ${ }_{\text {tmm }}$ resulted in data points more scattered around the 1:1 line with a small overprediction (less than one node) at the beginning of the season (when NN was lower than about seven nodes), and an underprediction afterwards that reached up to about two nodes at NN between 10 and 15 nodes (Figures $1 \mathrm{~B}$ and 1 D). For data presented in Figure 1, Pearson correlation coefficient was high for both $\operatorname{Soydev}_{\text {tmean }}(r=0.99)$ and for $\operatorname{Soydev}_{\text {tmm }}(r=0.99)$, observed and simulated $\mathrm{NN}$ were normally distributed at $1 \%$, and the variance of simulated data was not different from the variance of observed data according to the Bartlett test at $1 \%$. These results indicate that the Soydev ${ }_{\text {tmm }}$ version is superior to the Soydev tmean version of the node appearance model.

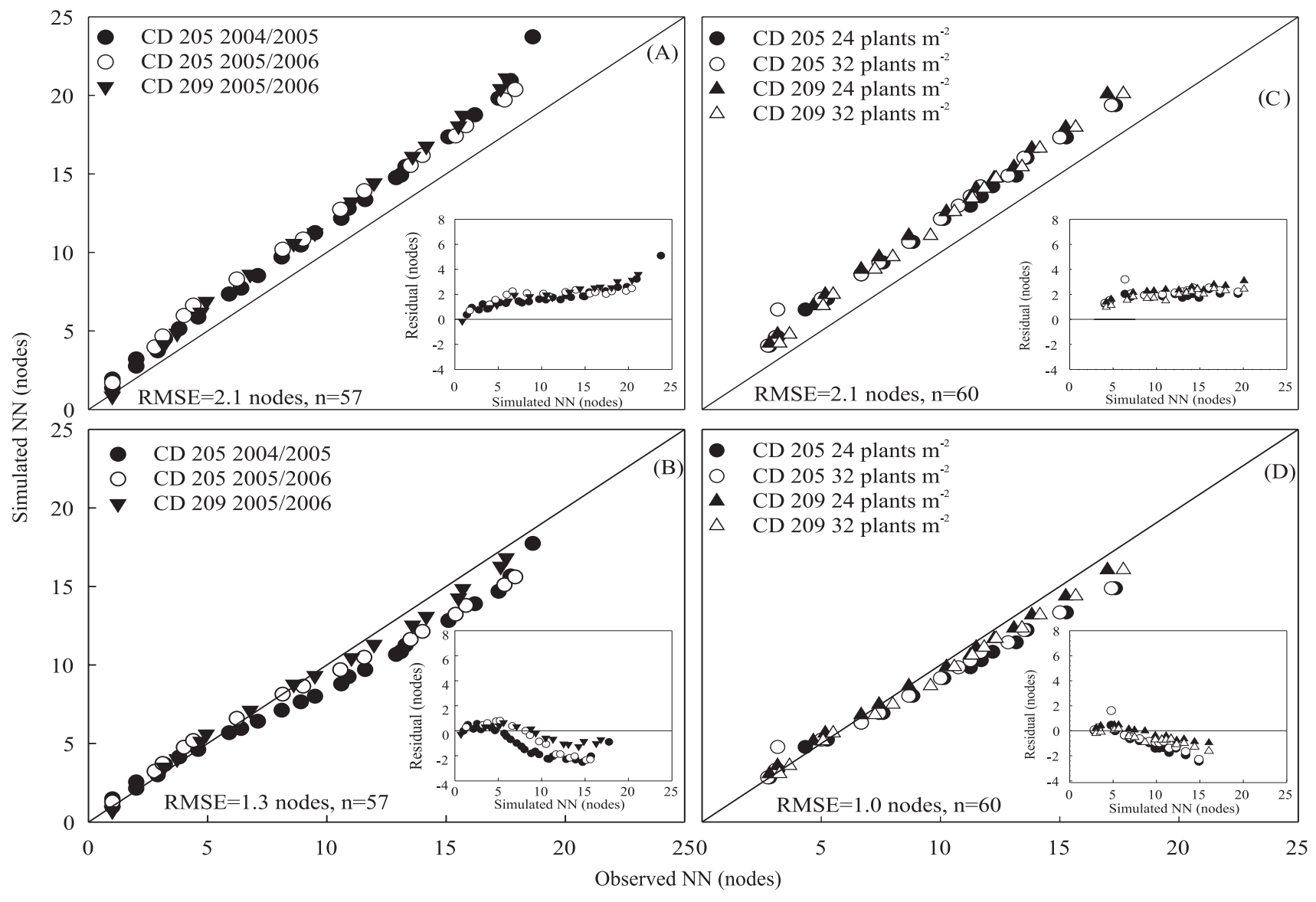

Figure 1. Simulated versus observed number of nodes (NN) in two soybean cultivars (CD 205 and CD 209) using two versions of the Soydev model during two growing seasons (2004/2005 and 2005/2006). (A) and (C) show the simulations with the Soydev model using mean air temperature in the $\mathrm{f}(\mathrm{T})\left(\operatorname{Soydev}_{\text {tmean }}\right)$, and (B) and (D) show the simulations with the Soydev model using daily minimum and maximum air temperature in the $\mathrm{f}(\mathrm{T})\left(\operatorname{Soydev}_{\mathrm{tmm}}\right)$. In (A) and (B) the plant density was 40 plants $\mathrm{m}^{-2}$ and in $(\mathrm{C})$ and (D) the plant density was 24 and 32 plants $\mathrm{m}^{-2}$. Plots of residual (simulated minus observed) versus simulated NN are shown in the insets. RMSE is the root mean square error of the simulation and $\mathrm{n}$ is the number of observations. 
The better performance of the Soydev ${ }_{\mathrm{tmm}}$ version over

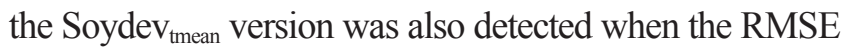
for cultivars CD 205 and CD 209 was calculated across growing seasons, cultivars, planting dates and plant densities (Table 2). The RMSE varied from 1.9 to 2.3 nodes with Soydev $_{\text {tmean }}$ and from 0.5 to 1.4 nodes with the Soydev $v_{\text {tmm }}$ model. The RMSE values obtained with the Soydev ${ }_{\text {tmm }}$ version in this study are within the range ( 0.3 to 1.5 nodes) obtained with the Soydev model for semi-determinate and indeterminate soybean cultivars grown under non-limiting water and nutrient conditions in a high-latitude temperate region in the USA (Setiyono et al., 2007).

The RMSE of the simulation of NN with the Soydev $\mathrm{tmm}_{\mathrm{tm}}$ version for each of the other eight cultivars in the second evaluation of the Soydev model is in Table 3. The lowest RMSE for cultivars BRS 66, CD 201 and CD 203 (0.6, 0.7 and 0.6 nodes, respectively) was when the Soydev tmm $_{\text {tm }}$ model was run with $\mathrm{NAR}_{\max }$ of cultivar CD 205, whereas the lowest RMSE for the other five cultivars (FT 9, Fundacep 39, CD 213 RR, CD 214 RR and CD 219 RR) $(1.0,1.4,2.4,1.6$ and 1.0 nodes, respectively) was when the Soydev ${ }_{\text {tmm }}$ model was run with NAR max $_{\text {max }}$ of cultivar CD 209. The RMSE for cultivars BRS 66, CD 201 and CD 203 increased only by 0.1 or 0.2 nodes when the $\mathrm{NAR}_{\max }$ of cultivar CD 209 was used, resulting in lower RMSE (0.8 nodes) than the RMSE for the other five cultivars with the $\mathrm{NAR}_{\text {max }}$ of cultivar CD 209. Therefore, when Soydev ${ }_{\mathrm{tmm}}$ was run with $\mathrm{NAR}_{\max }$ estimated for cultivar CD 209 for all the other eight cultivars (i.e., without cultivar-specific calibration), the RMSE varied from 0.8 to 2.4 nodes, and only two cultivars (CD 213 RR and CD 214 RR) had RMSE outside the range of 0.3 to 1.5 nodes reported by Setiyono et al. (2007) for 22 cultivars using cultivar-specific calibration. For data presented in Table 3, Pearson correlation was high for both $\operatorname{Soydev}_{\text {tmean }}(\mathrm{r}=0.98)$ and for $\operatorname{Soydev}_{\mathrm{tmm}}(\mathrm{r}=0.98)$, observed and simulated NN were normally distributed at $1 \%$, and the variance of simulated data was not different from the variance of observed data according to the Bartlett test at $1 \%$. These results indicate that NAR is a trait that varies little among the soybean genotypes and one single $\mathrm{NAR}_{\max }$ value can represent a group of genotypes with no major loss of predictive ability by the Soydev model.

The RMSE values (Table 3) were associated with the maturity group of the cultivars (Table 1), but no clear trend could be detected. For instance, CD 205 (a mid-late genotype) reached R1 3-5 days later than CD 209 (a medium genotype), and when the Soydev ${ }_{\text {tmm }}$ was run with NAR $_{\text {max }}$ of CD 209 it gave lower RMSE for CD 219 RR (a mid-late genotype). A lack of association between the performance of a NN simulation model with maturity group for the determinate soybean cultivars used in the present study is consistent with the results reported by Setiyono et al. (2007) for semi-determinate and indeterminate soybean cultivars and indicates that vegetative development (node appearance) is independent of reproductive development in soybean, even though the former overlaps the latter.

The 2004/2005 growing season was quite dry compared to the other two growing seasons. Even though no apparent symptoms of water stress (wilting or leaf rolling) was observed in the plants, the duration of the emergence (EM) - R1 phase of cultivar CD 205 was slightly shorter in 2004/2005 (56 days) than in 2005/2006 (62 days) and 2006/2007 (58 days). This reduction in the EM-R1 phase in 2004/2005 may have occurred due to a partial stomatal closure in an attempt to save water and keep cell turgescence that might have led to a slight increase in canopy temperature, which may hasten crop development. In terms of Soydev performance, RMSE with the Soydev tmm $_{\text {was }}$ the lowest in 2004/2005 (Table 3), indicating that node appearance was not affected by the lower precipitation during this growing season.

Table 2. Values of root mean square error (RMSE) for the simulation of node number in two soybean cultivars using two versions of the Soydev model during three growing seasons.

\begin{tabular}{|c|c|c|c|c|c|c|}
\hline \multirow[t]{2}{*}{ Cultivar } & \multirow[t]{2}{*}{$\begin{array}{l}\text { Growing } \\
\text { season }\end{array}$} & \multirow[t]{2}{*}{$\mathrm{n}$} & \multirow[t]{2}{*}{$\begin{array}{l}\text { Plant density } \\
\left(\text { plants } \mathrm{m}^{-2}\right)\end{array}$} & \multirow[t]{2}{*}{$\begin{array}{c}\text { FNN } \\
\text { (nodes) }^{(1)}\end{array}$} & \multicolumn{2}{|c|}{$\begin{array}{l}\text { RMSE } \\
\text { (nodes) }\end{array}$} \\
\hline & & & & & Soydev $_{\text {tmean }}$ & Soydev $_{\mathrm{tmm}}$ \\
\hline CD 205 & $2004 / 2005$ & 25 & 40 & 20.5 & 1.9 & 1.4 \\
\hline CD 205 & $2005 / 2006$ & 16 & 40 & 20.8 & 2.0 & 1.4 \\
\hline CD 205 & $2006 / 2007$ & 15 & 32 & 18.7 & 2.2 & 1.1 \\
\hline CD 205 & $2006 / 2007$ & 15 & 24 & 19.0 & 1.9 & 1.2 \\
\hline CD 209 & $2005 / 2006$ & 16 & 40 & 20.1 & 2.2 & 0.7 \\
\hline CD 209 & $2006 / 2007$ & 15 & 32 & 17.8 & 1.9 & 0.8 \\
\hline CD 209 & $2006 / 2007$ & 15 & 24 & 17.6 & 2.3 & 0.5 \\
\hline
\end{tabular}

${ }^{(1)} \mathrm{FNN}$, average main stem final node number observed. 
The results of this study indicate that the simulation of node number in soybean with Soydev can be improved by using the minimum and maximum air temperature as the input for calculating the temperature response function (Soydev $_{\text {tmm }}$ version). Similar results were reported for winter wheat (Xue et al., 2004) and maize (Streck et al., 2008c). When air temperature is near the cardinal temperatures, the response of crop development to temperature falls into the nonlinear range and in this situation the approach of calculating an $\mathrm{f}(\mathrm{T})$ for $\mathrm{TN}$ and an $\mathrm{f}(\mathrm{T})$ for TX is more appropriate than calculating an $\mathrm{f}(\mathrm{T})$ for $\mathrm{T}_{\text {mean }}$ (Xue et al., 2004; Streck et al., 2008c). In this study, during the node appearance phase, the highest TX were 39, 38.6 and $37.4^{\circ} \mathrm{C}$, and TX was higher than $37^{\circ} \mathrm{C}$ in 8,7 and 1 day during the 2004/2005, 2005/2006 and 2006/2007 growing seasons, respectively. These TX values are near the $T_{\max }$ for node appearance in soybean $\left(40^{\circ} \mathrm{C}\right)$. Therefore, the hypothesis tested in the present study, that the approach of calculating $\mathrm{f}(\mathrm{T})$ based on daily minimum and maximum air temperatures improves the simulation of soybean $\mathrm{NN}$ using Soydev in comparison to the original version of the model under Brazilian conditions, has been confirmed.

Simulations of NN with Soydev ${ }_{\text {tmm }}$ for cultivars CD 205 and CD 209 grown at plant densities of 32 and 24 plants $\mathrm{m}^{-2}$ were good (Table 2), with RMSE varying from 0.5 nodes (CD 209) to 1.2 nodes (CD 205). These results indicate that changing plant density in the range from 24 to 40 plants $\mathrm{m}^{-2}$ has no considerable impact on node appearance rate and that Soydev $v_{\text {tmm }}$ can be used to predict NN with no

Table 3. Values of root mean square error (RMSE) for the simulation of node number in eight soybean cultivars with the version of the Soydev model that uses minimum and maximum daily air temperature as the input to calculate the $\mathrm{f}(\mathrm{T})\left(\right.$ Soydev $\left._{\mathrm{tmm}}\right)$, during two growing seasons.

\begin{tabular}{|c|c|c|c|c|}
\hline \multirow[t]{2}{*}{ Cultivars } & \multirow[t]{2}{*}{$\mathrm{n}$} & \multirow[t]{2}{*}{ FNN (nodes) ${ }^{(1)}$} & \multicolumn{2}{|c|}{ RMSE (nodes) } \\
\hline & & & Soydev $_{1}^{(2)}$ & $\operatorname{Soydev}_{2}^{(3)}$ \\
\hline & \multicolumn{4}{|c|}{$2004 / 2005$ growing season } \\
\hline BRS 66 & 27 & 21.5 & 0.6 & 0.8 \\
\hline CD 201 & 27 & 21.0 & 0.7 & 0.8 \\
\hline CD 203 & 27 & 21.0 & 0.6 & 0.8 \\
\hline FT Nobre & 27 & 21.8 & 1.7 & 1.0 \\
\hline Fundacep 39 & 27 & 22.0 & 2.0 & 1.4 \\
\hline & \multicolumn{4}{|c|}{ 2005/2006 growing season } \\
\hline CD 213 RR & 18 & 22.8 & 3.2 & 2.4 \\
\hline CD 214 RR & 18 & 22.3 & 2.4 & 1.6 \\
\hline CD $219 \mathrm{RR}$ & 18 & 21.5 & 1.8 & 1.0 \\
\hline
\end{tabular}

${ }^{(1)} \mathrm{FNN}$, average main stem final node number observed. ${ }^{(2)}$ Soydev model run with maximum daily node appearance rate $\left(\mathrm{NAR}_{\max }\right)$ of cultivar CD 205 (0.3736 nodes per day). ${ }^{(3)}$ Soydev model run with $\mathrm{NAR}_{\max }$ of cultivar CD 209 (0.4027 nodes per day). additional input or calibration for plant density, which is an advantage from a modeling viewpoint. Another important result of the present study was that $\mathrm{NN}$ was well simulated in a dry year (2004/2005) with model calibration for a wet year (2006/2007). Furthermore, the RMSE of six out of eight cultivars was low ( 0.8 to 1.4 nodes) when the model was run with a simple $\mathrm{NAR}_{\max }$ value. These results indicate robustness and generality of the Soydev model, and confirm that this model is suitable for practical applications because of its reduced need for genotype-specific calibration (Setiyono et al., 2007). One practical application of the NN simulations with the Soydev model is to describe the V-Stages of a soybean crop. In order to calculate the V-Stage, one has to subtract $\mathrm{NN}$ by one, i.e., if the simulated $\mathrm{NN}=2$, then crop is at V1 (unifoliolate leaf pair); if $\mathrm{NN}=3$, then crop is at V2 (first trifoliolate leaf), and so forth.

\section{Conclusions}

1. The simulation of node number in soybean is improved when daily minimum and maximum air temperatures are used as input for the temperature response function $\left(\mathrm{Soydev}_{\mathrm{tmm}}\right.$ version) compared to using daily mean temperature (Soydev tmean $_{\text {version). }}$

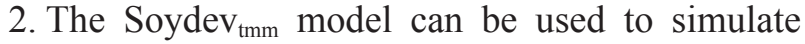
main stem node number in soybean when plant density varies from 24 to 40 plants $\mathrm{m}^{-2}$ with no additional input or calibration.

3. Main stem node number of determinate stem habit soybean cultivars can be simulated for several cultivars using only one set of model coefficients $\left(\mathrm{NAR}_{\max }\right.$ and cardinal temperatures).

4. The simulation of node numbers in soybean grown in rainfed conditions is good in a dry year using model calibration from a wet year.

\section{Acknowledgements}

ToConselho Nacionalde DesenvolvimentoCientífico e Tecnológico and Coordenação de Aperfeiçoamento de Pessoal de Nível Superior, for scholarships.

\section{References}

ASSOCIAÇÃO DOS PRODUTORES E COMERCIANTES DE SEMENTES DO RIO GRANDE DO SUL. Descrição de cultivares: soja. Available at: <http://www.apassul.com.br/ conteudo.asp? content $=12 \& \mathrm{a}=$ view $\& \mathrm{ID}=12>$. Acessed on: 28 mar. 2006.

COOPERATIVA CENTRAL DE PESQUISA AGRÍCOLA. Produtos: soja. Available at: <http://www.coodetec.com.br/ >. Acessed on: 28 mar. 2006. 
FEHR, W.R.; CAVINESS, C.E. Stages of soybean development. Ames: Iowa State University of Science and Technology, 1977. 15p. (Special Report, 80).

FUNDAÇÃO CENTRO DE EXPERIMENTAÇÃO E PESQUISA. Produtos: variedades de soja. Available at: $<$ http://www.fundacep.com. br/>. Acessed on: 28 mar. 2006.

HARISSON, S.R. Regression of a model on real-system output: an invalid test of model validity. Agricultural Systems, v.34, p.183-190, 1990.

JANSSEN,P.H.M.; HEUBERGER, P.S.C.Calibration of process-oriented models. Ecological Modelling, v.83, p.55-66, 1995.

JOHNSON, S.R. How a soybean plant develops. Ames: Iowa State University of Science and Technology, 1997. 18p. (Special Report, 53).

JONES, J.W.; WHITE, J.; BOOTE, K.; HOOGENBOOM, G.; PORTER, C.H. Phenology module in DSSAT v. 4.0: documentation and source code listing. Gainesville: University of Florida, 2000. 98p.

JONES, P.G.; LAING, D.R. Simulation of the phenology of soybean. Agricultural Systems, v.3, p.295-311, 1978.

MAJOR, D.J.; JOHNSON, D.R.; TANNER, J.W.; ANDERSON, I.C. Effects of day length and temperature on soybean development. Crop Science, v.15, p.174-179, 1975.

MARTIN, T.N.; STORCK, L.; DOURADO NETO, D. Simulação estocástica da radiação fotossinteticamente ativa e da temperatura do ar por diferentes métodos. Pesquisa Agropecuária Brasileira, v.42, p.1211-1219, 2007.

MARTINS, F.B.; STRECK, N.A. Aparecimento de folhas em mudas de eucalipto estimado por dois modelos. Pesquisa Agropecuária Brasileira, v.42, p.1091-1100, 2007.

MITCHELL, P.L. Misuse of regression for empirical validation of models. Agricultural Systems, v.54, p.313-326, 1997.

PIPER, E.L.; BOOTE, K.J.; JONES, J.W.; GRIMM, S.S. Comparison of two phenology models for predicting flowering and maturity date of soybean. Crop Science, v.36, p.1606-1614, 1996.

REUNIÃO DE PESQUISA DE SOJA DA REGIÃO SUL, 28., 2000, Santa Maria. Anais. Santa Maria: Universidade Federal de Santa Maria, 2000. 148p.

REUNIÃO DE PESQUISA DE SOJA DA REGIÃO SUL, 34., 2006, Pelotas. Atas e resumos. Pelotas: Embrapa Clima Temperado, 2006. $237 \mathrm{p}$.

REUNIÃO DE PESQUISA DE SOJA DA REGIÃO SUL, 35., 2007, Santa Maria. Atas e resumos. Santa Maria: Universidade Federal de Santa Maria. 203p.
SETIYONO, T.D.; WEISS, A.; SPECHT, J.; BASTIDAS, A.M.; CASSMAN K.G.; DOBERMANN, A. Understanding and modeling the effect of temperature and day length on soybean phenology under high-yield conditions. Field Crops Research, v.100, p.257-271, 2007.

SINCLAIR, T.R. Water and nitrogen limitations in soybean grain productivity. I. Model development. Field Crops Research, v.15, p.125-141, 1986.

SINCLAIR, T.R.; NEUMAIER, N.; FARIAS, J.R.B.; NEPOMUCENO, A.L. Comparison of vegetative development in soybean cultivars for low-latitude environments. Field Crops Research, v.92, p.53-59, 2005.

STRECK, E.V.; KÄMPF, N.; DALMOLIN, R.S.D.; KLAMT, E.; NASCIMENTO, P.C. do; GIASSON, E.; PINTO, L.F.S. Solos do Rio Grande do Sul. 2 ed. Porto Alegre: UFRGS: Emater/RS, 2008a. 222p.

STRECK, N.A.; BOSCO, L.C.; LAGO, I. Simulating leaf appearance in rice. Agronomy Journal, v.100, p.490-501, 2008b.

STRECK, N.A.; DE PAULA, F.L.M.; BISOGNIN, D.A.; HELDWEIN, A.B.; DELLAI, J. Simulating the development of field grown potato (Solanum tuberosum L.). Agricultural and Forest Meteorology, v.142, p.1-11, 2007.

STRECK, N.A.; LAGO, I.; BURIOL, G.A.; HELDWEIN, A.B.; TIBOLA, T. A non-linear model to simulate node appearance in muskmelon (Cucumis melo L.) grown inside plastic greenhouse as a function of air temperature. Revista Brasileira de Agrometeorologia, v.14, p.210-216, 2006.

STRECK, N.A.; LAGO, I.; GABRIEL, L.F.; SAMBORANHA, F.K. Simulating maize phenology as a function of air temperature with a linear and a nonlinear model. Pesquisa Agropecuária Brasileira, v.43, p.449-455, 2008c.

STRECK, N.A.; WEISS, A.; XUE, Q.; BAENZIGER, P.S. Improving predictions of developmental stages in winter wheat: a modified Wang and Engel model. Agricultural and Forest Meteorology, v.115, p.139-150, 2003a.

STRECK, N.A.; WEISS, A.; XUE, Q.; BAENZIGER, P.S. Incorporating a chronology response into the prediction of leaf appearance rate in winter wheat. Annals of Botany, v.92, p.181-190, 2003 b.

WOLF, J. Comparison of two soya bean simulation models under climate change. I. Model calibration and sensitivity analyses. Climate Research, v.20, p.55-70, 2002.

XUE, Q.; WEISS, A.; BAENZIGER, P.S. Predicting leaf appearance in field-grown winter wheat: evaluating linear and non-linear models. Ecological Modelling, v.175, p.261-270, 2004.

Received on January 19, 2009 and accepted on July $1^{\text {st }}, 2009$

Pesq. agropec. bras., Brasília, v.44, n.7, p.661-668, jul. 2009 